\title{
An Electron Microscopic Study of Keratinization in the Mouse Intraepidermal Sweat Duct
}

\author{
Hiroyuki SuzukI
}

\author{
Received February 13, 1973
}

Summary. The keratinization of intraepidermal sweat duct cells in the mouse foot pad was studied by electron microscopy.

The intraepidermal sweat duct is composed of a single layer of luminal cells lining the ductal lumen and one to three layers of peripheral cells which separate the luminal cells from the epidermal keratinocytes. It is remarkable that cells of the intraepidermal sweat duct undergo keratinization much earlier than the surrounding epidermal keratinocytes.

The luminal cells keratinize incompletely. Numerous tonofilaments are seen, but they have little tendency to form tonofibrils. Keratohyalin granules spherical in shape and surrounded by numerous ribosomes are detected in the cytoplasm, but lamellar granules of Odland are not seen and thickening of the cell membrane does not occur throughout the path of the intraepidermal sweat duct. Consequently, the luminal cells are shed into the ductal lumen without forming the keratin pattern.

On the other hand, the peripheral cells keratinize completely like the epidermal keratinocytes. Tonofilaments are abundant and most of them are grouped into tonofibrils. In the duct situated at the level of the lower portion of the stratum spinosum, lamellar granules are observed and discharged the internal substances into the intercellular space between the adjacent peripheral cells and between the peripheral and luminal cells. Acid phosphatase activity is demonstrated both on the intracellular lamellar granules and on the lamellar structures derived from the lamellar granules in the intercellular space. Spherical keratohyalin granules are also seen in the peripheral cells. Sometimes, spherical dense granules morphologically identical with the cytoplasmic spherical keratohyalin granules are observed in the nuclei. In the level of the stratum granulosum, the peripheral cells have thickened plasma membrane and typical keratin pattern is seen in the cytoplasm. The completely keratinized peripheral cells are shed into the ductal lumen in the lower part of the stratum corneum.

From the base of the rete ridge to the point where the sweat duct opens onto the surface of the skin, the eccrine sweat duct traverses the epidermis and follows a tortuous path. This portion of the eccrine sweat gland being distinct from the surrounding epidermis has been designated as the intraepidermal sweat duct (MonTAGNA, 1962; НАSнімото et al., 1966) or the epidermal sweat duct (Zelickson, 1961). In cross sections through the duct, a single layer of luminal cells lines the lumen and one or more layers of peripheral cells separate the luminal cells from the adjoining epidermal keratinocytes. Some investigators referred to the duct as the epidermal sweat duct unit (LoBITz et al, 1954). ELLIs (1968) supported the concept of epidermal sweat duct unit, since in some epidermal lesions such as senile keratosis, this portion is relatively unaffected (LoBITz et al., 1954) and the cells of the intraepidermal sweat duct contain no pigment, even in the skin of Negros. Furthermore, it is known that the cells of this portion keratinize in a specific process, as they ascend through the 
epidermis; and their keratinization differs from that of the epidermal keratinocytes.

It is significant to study the keratinization of this portion by electron microscopy in order to better understand keratinization. However, in the previous investigations, no detailed information about the keratinization of the intraepidermal sweat duct has been elicited except for a few descriptions, and most studies have been concei1trated upon human material (HibBs, 1958; Charles, 1960; Zelickson, 1961; Hashimoto et al., 1966; Ellis, 1967, 1968; Наsнiмото, 1971a, b).

In animal material, electron microscopic studies of the intraepidermal sweat duct are very few in number. A brief description of the mouse intraepidermal sweat duct by Kurosumi and Kurosumi (1970) is the only paper. No histochemical observations of the intraepidermal sweat duct were described in the past literature.

In this study, keratinization of the intraepidermal sweat duct in the mouse foot pad is described in detail. Acid phosphatase activity is examined and keratinization of the intraepidermal sweat duct is compared with that of the normal epidermal keratinocytes.

\section{Materials and Methods}

Samples of skin were taken from the mouse foot pad, cut into small pieces and fixed in a mixture of $2 \%$ osmium tetroxide buffered with phosphate and $2.5 \%$ glutaraldehyde at $4^{\circ} \mathrm{C}$ for $2 \mathrm{hrs}$ (Kurosumi, 1970). After dehydration with a series of ascending concentrations of ethanol, the specimens were embedded in Epon 812 (LuFT, 1961). In addition, acid phosphatase activity was examined by a modified Gomori method (BARKA and ANDERson, 1963). Ultrathin sections were cut on a Porter-Blum MT-2 microtome and doubly stained with uranyl acetate and lead citrate or uranyl acetate alone. They were examined with a Hitachi HU-11D electron microscope under the accelerating potential of $75 \mathrm{kV}$.

\section{Observations}

\section{Basal portion of rete ridges and lower part of the stratum spinosum. (Fig. 1, 2)}

Luminal cells. A single layer of luminal cells lines the ductal lumen and two, sometimes three, cells form the inner rim of the duct characterized by a semilunar configuration of the lumen (Fig. 1). The cells are oval or crescent in shape. Their nuclei usually containing nucleoli are spherical, oval or somewhat undulant. The luminal surface is covered with short stumpy microvilli containing fine filamentous components (Fig. 1, 2). An extraneous fuzzy coating is found on these microvilli. In the cytoplasm scattered mitochondria and dense bodies are seen. The roughsurfaced endoplasmic reticulum appears in small amount. Free ribosomes are found in large number in the cytoplasm. Small Golgi apparatus can be seen near the nucleus. Small vesicles are scattered in the cytoplasm. Tonofilaments are dispersed throughout the cytoplasm, but they are most abundant at the periluminal area (Fig. 1). In the luminal cells at the level of the lower layer of the stratum spinosum, small, spherical keratohyalin granules are detected within an area where free ribosomes aggregate (Fig. 2). Large spherical keratohyalin granules are usually surrounded by numerous ribosomes. Where two luminal cells join at the luminal side, a typical junctional complex is formed. At the lateral surface of the luminal cells, 
the cell membrane is often folded between desmosomes and has many villous projections. Desmosomes are developed between the luminal and the peripheral cells, but they are smaller than those among the ordinary keratinocytes. The desmosome is seen to have an internal structure when it is cut along a plane perpendicular to the surface of the cell. The cell membranes of adjacent cells are thickened to form the attachment plaque and many of the tonofilaments are attached to it and turn back into the cytoplasm. A single, intercellular contact layer parallel to the plasma membrane is placed at the central portion of the intercellular space, but often they are not clearly defined at this level.

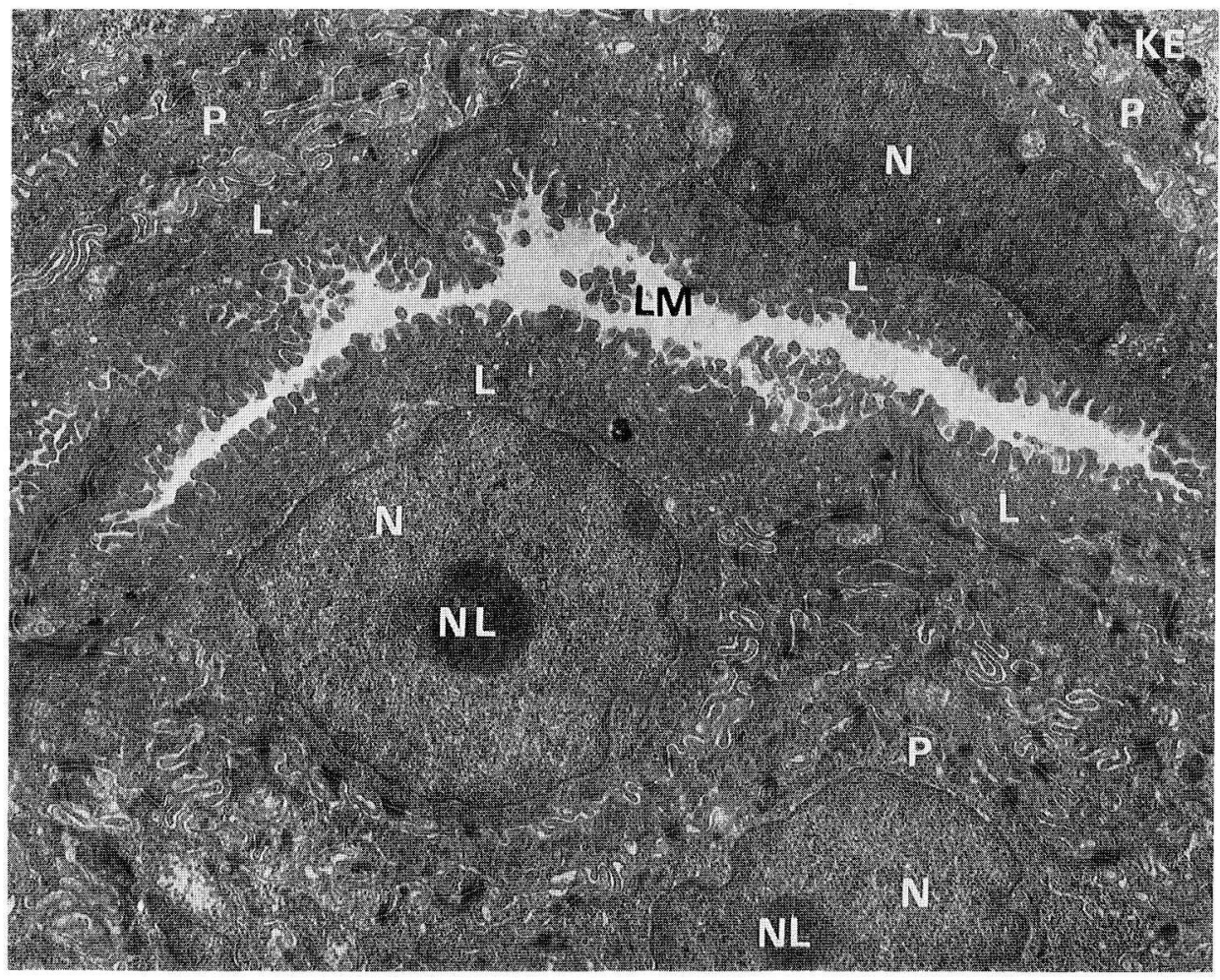

Fig. 1. The eccrine sweat duct of the mouse plautar sweat glands passing through the lower part of the stratum spinosum. A single layer of luminal cells $(L)$ form the inner rim of the semilunar ductal lumen $(L M)$, and a single layer of peripheral cells $(P)$ separates the luminal cells from the adjoining epidermal keratinocytes $(K E) . N$ nucleus, $N L$ nucleolus. $\quad \times 7,300$

Peripheral cells. The outer layer of the duct is composed of a single layer of peripheral cells which separate the luminal cells from the adjoining keratinocytes. At this level, the peripheral cells are indistinguishable from the adjoining epidermal keratinocytes except for their semilunar shapes along the luminal cells. Their nuclei are oval or somewhat undulant in shape and contain one or more nucleoli. Scattered mitochondria, numerous free ribosomes, and tonofilaments are seen in the cytoplasm. At the portion where the peripheral cells make contact with the adjoining keratinocyte, the cell membrane is intricately folded. Prominent desmosomes are developed 


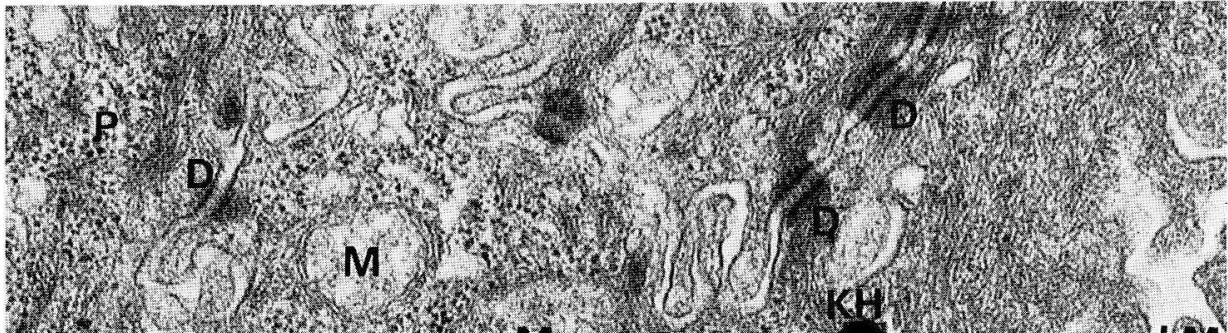

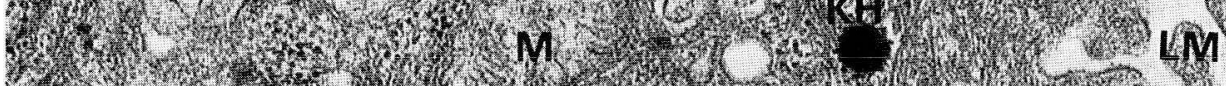
37 - W

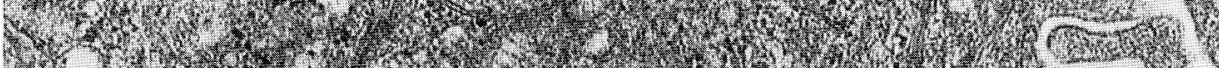

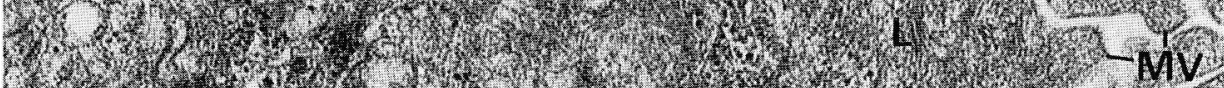

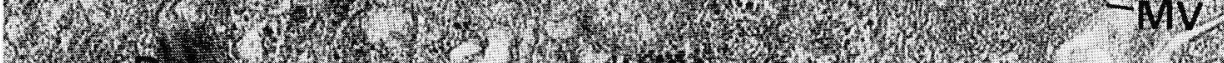
26. 10. (3)

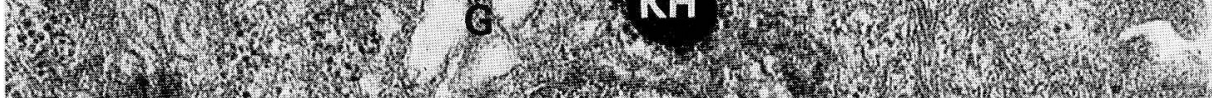

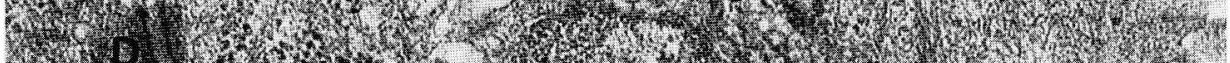

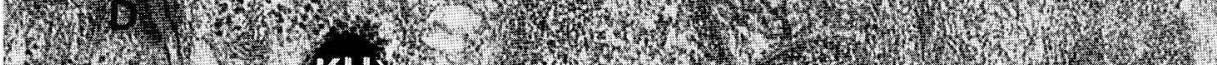

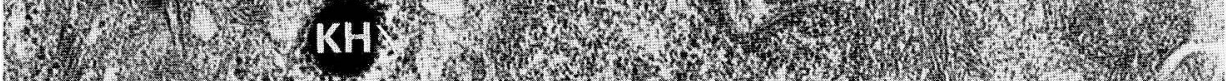

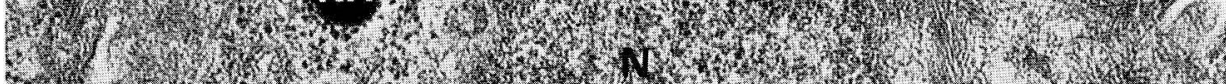

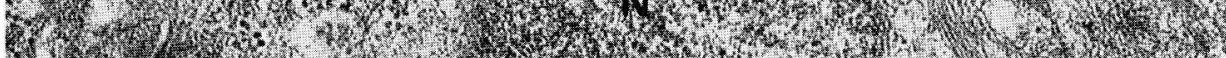
2.

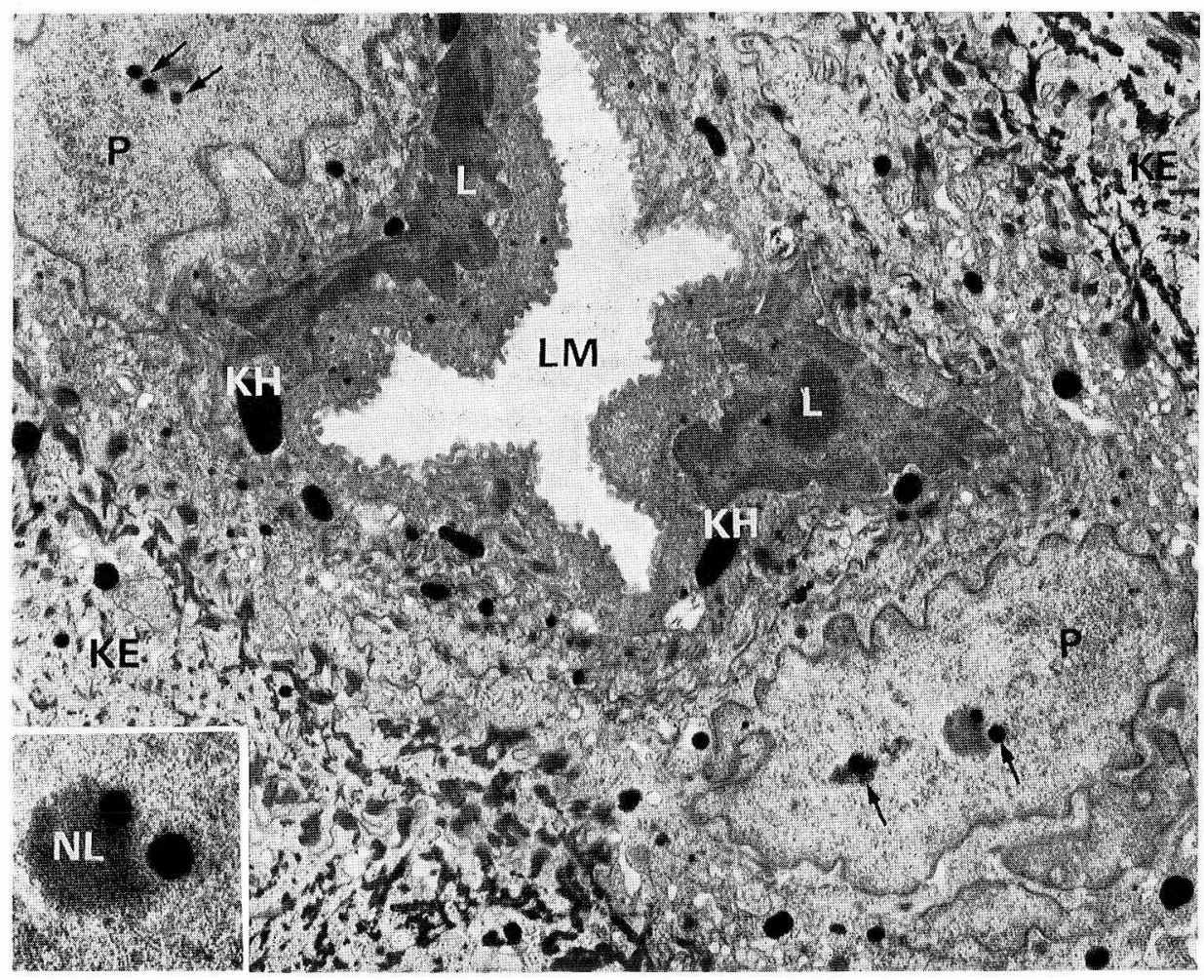


between the peripheral cells and between the peripheral cells and adjoining keratinocytes.

Middle and upper parts of the stratum spinosum (Fig. 3-5).

Luminal cells. The luminal cells being in a single layer appear often semilunar in cross section with a curved long axis surrounding the lumen and contain crescent,

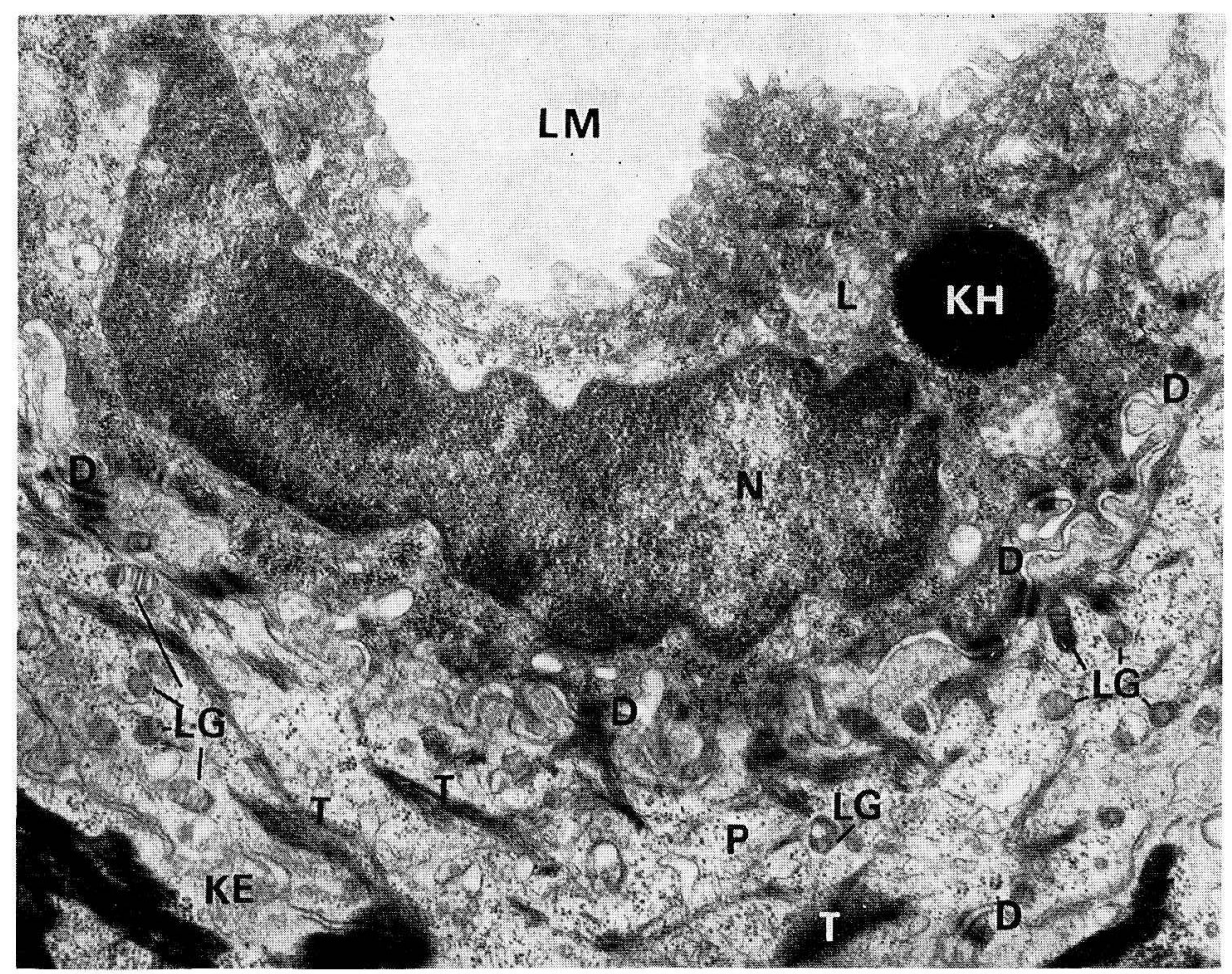

Fig. 4. A part of the sweat duct in the upper part of the stratum spinosum, a crescent-shaped, indented nucleus $(N)$ and spherical keratohyalin granules $(K H)$ are seen in the luminal cells $(L)$. In the periperal cells $(P)$, lamellar granules $(L G)$ containing lamellar structures are seen and tonofilaments are bundled into tonofibrils $(T)$. Desmosomes $(D)$ are developed between the luminal and the peripheral cells. $L M$ ductal lumen, $K E$ keratinocyte. $\quad \times 20,000$

Fig. 2. Parts of the luminal $(L)$ and peripheral $(P)$ cells of the sweat duct found in the lower part of the stratum spinosum. Keratohyalin substances $(K H)$ appear within an area where free ribosomes aggregate. They deposit as spherical granules. Small Golgi apparatus $(G)$, mitochondria $(M)$ and numerous free ribosomes are seen in the cytoplasm. Tonofilaments are abundant at the periluminal area. Numerous microvilli $(M V)$ containing filamentous components extend into the ductal lumen $(L M)$ from the luminal surface. Desmosomes $(D)$ are developed between the luminal and peripheral cells. $N$ nucleus. $\times 33,000$

Fig. 3. A part of an intraepidermal sweat duct in the upper part of the stratum spinosum; opaque luminal cells $(L)$ form an X-shaped lumen $(L M)$ and the peripheral cells $(P)$ surround them. Spherical or ovoid keratohyalin granules of various sizes $(K H)$ are seen in both cells. Spherical dense granules are observed in the nuclei of peripheral cells (arrows). Some of them are situated around or on the nucleoli $(N L)$ as shown in the inset. $K E$ keratinocyte. $\times 60,000$ (inset: $\times 20,000$ ) 
triangular or indented nuclei (Fig. 3-5). The nucleus has usually one or more nucleoli. In cross section, the lumen is mostly obliterated and X-or H-shaped (Fig. 3). Scattered mitochondria, numerous free ribosomes, small Golgi apparatus and vesicles of various sizes are seen in the cytoplasm. Tonofilaments are abundant in the cytoplasm, especially in the periluminal area. The lateral surface of the luminal cell possesses an intricate series of cytoplasmic protrusions which interdigitate with those of the adjoining keratinocytes (Fig. 4). Desmosomes are developed between the luminal and the peripheral cells, but they are small in size.

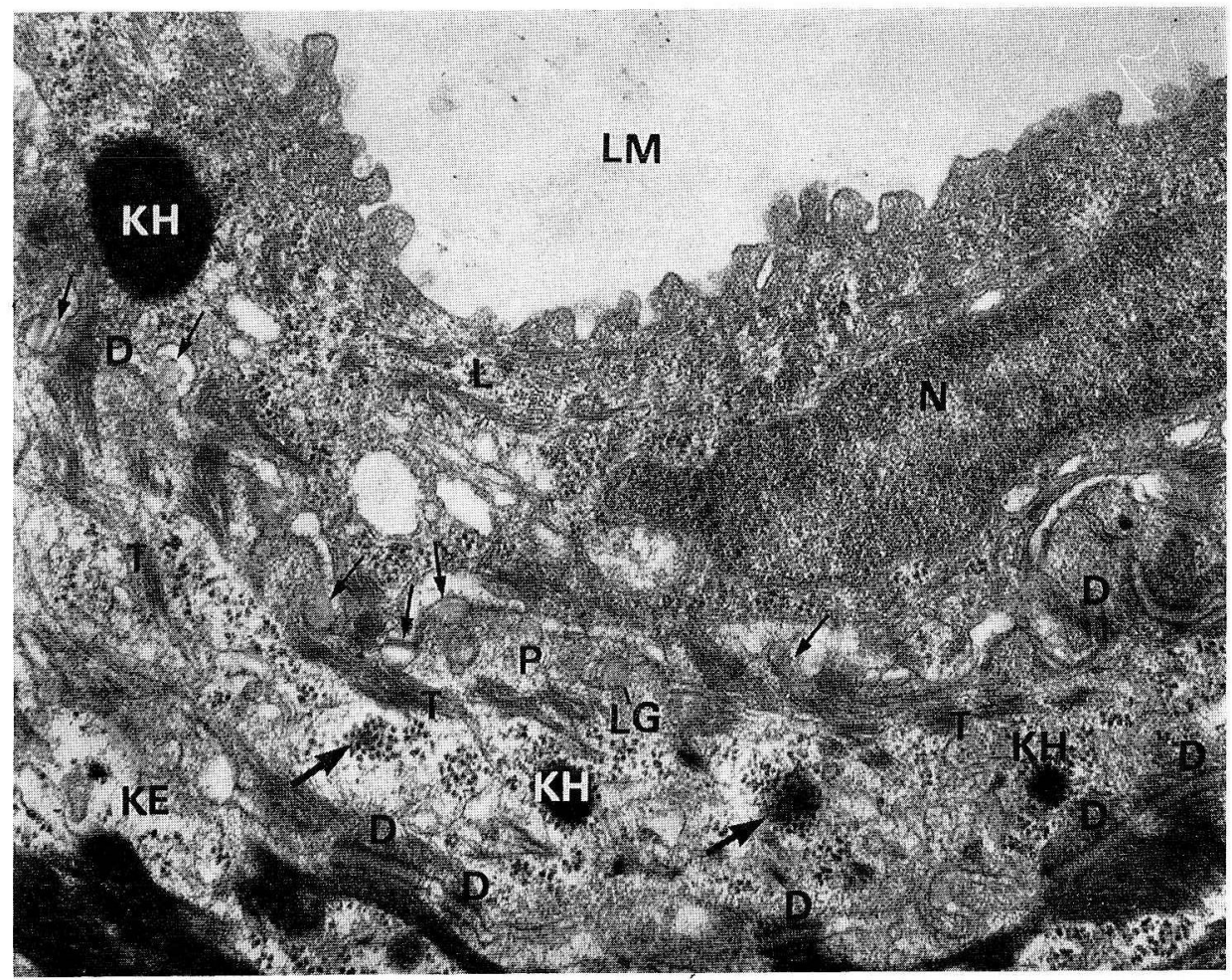

Fig. 5. A part of the sweat duct consisting of the luminal $(L)$ and peripheral $(P)$ cells appearing in the upper part of the stratum spinosum. The luminal cells appear more opaque than the peripheral cells. Spherical keratohyalin granules $(K H)$ surrounded by numerous ribosomes are seen in the cytoplasm in both cells. The aggregations of the ribosomes (large arrows) are observed in the cytoplasm of peripheral cells, and the keratohyalin substance may be seen within them. Lamellar granules $(L G)$ discharge their content into the intercellular space between the luminal and peripheral cells (small arrows). Tonofibrils $(T)$ are moderately developed in the peripheral cells. Desmosomes $(D)$ between the luminal and peripheral cells are smaller in size than those between the two peripheral cells and these adjoining keratinocytes $(K E)$. $L M$ ductal lumen, $N$ nucleus. $\times 29,000$

Peripheral cells. The outer lining of the duct is composed of a single layer of peripheral cells. These cells are larger and more lucent than the luminal cells, and contain large, indented nuclei containing one or more nucleoli. The karyoplasm looks more lucent than that of the luminal cells. Ocassionally, spherical dense granules of various sizes are detected in the karyoplasm and some of them are situated 
around or on the nucleoli (Fig. 3). Several mitochondria, small rough-surfaced endoplasmic reticulum, small vesicles and numerous free ribosomes are seen in the cytoplasm. Most of the tonofilaments are bundled into tonofibrils. They run parallel to the long axis of the cell though some of them maintain their attachment to the desmosomes. Sometimes, free ribosomes aggregate in the cytoplasm of peripheral cells and keratohyalin substances occur within an area where they aggregate (Fig. 5). Spherical keratohyalin granules surrounded by numerous ribosomes are also seen throughout the cytoplasm. Lamellar granules of Odland containing inner lamellar structures are detected in the cytoplasm (Fig. 4). They migrate toward the peripheral portion of the cell and consequently the internal substances of granules are discharged into the intercellular space between the luminal and peripheral cells (Fig. 5). Typical desmosomes are well developed between the peripheral cells and adjoining keratinocytes.

\section{The stratum granulosum (Fig. 6, 7)}

Luminal cells. The cells in a single layer become somewhat flattened. The irregularly shaped nuclei containing nucleoli can be seen. Cell organelles decrease in

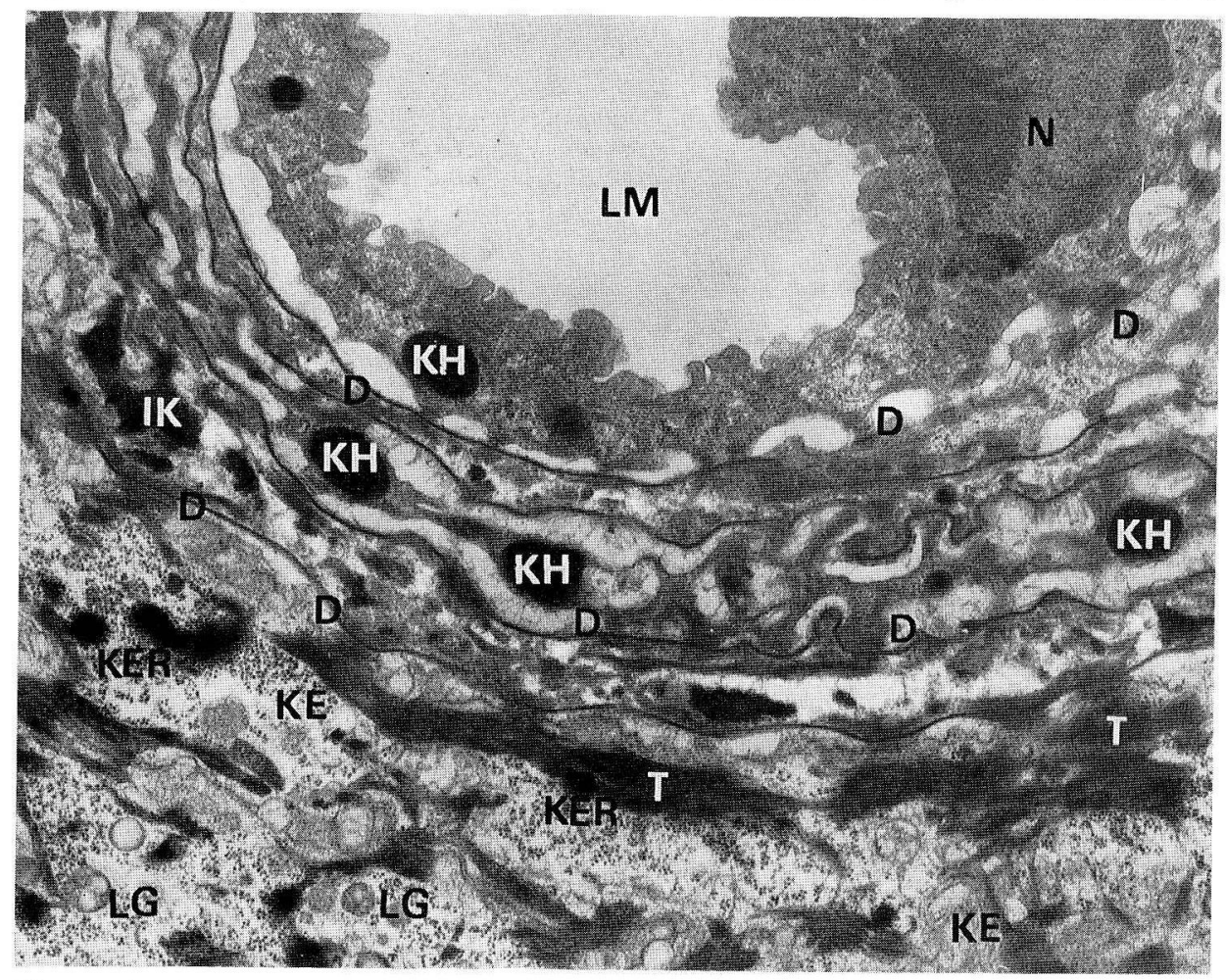

Fig. 6. At the level of the stratum granulosum, the peripheral cells become flattened and the cell membrane becomes thicker. Most of their organelles disappear though spherical $(K H)$ or irregularly shaped $(I K)$ keratohyalin granules remain. In the luminal cells the nucleus $(N)$ and spherical keratohyalin granules $(K H)$ are seen. Desmosomes $(D)$ are observed though they decrease in number. Lamellar granules $(L G)$, tonofibrils $(T)$ and keratohyalin granules $(K E R)$ are seen in the adjacent keratinocytes $(K E) . \quad L M$ ductal lumen. $\times 6,000$ 
number, though free ribosomes and tonofilaments are abundant in the lower layer of the stratum granulosum (Fig. 6). The cytoplasm looks opaque due to the abundance of closely packed tonofilaments. Several spherical or oval keratohyalin granules are seen. In the upper part, nuclei and organelles are diminished in size and the cytoplasm is filled with electron opaque granular or amorphous substances. Microvilli remain on the luminal surface, but they decrease in number and some of them become thicker in total width. The luminal cells are firmly joined with the peripheral cells by small desmosomes, though the intercellular space between both cells is occasionally dilated (Fig. 6). Lamellar structures derived from lamellar granules are often seen in the intercellular space between the luminal and peripheral cells, and usually situated in parallel with the cell membrane (Fig. 7).

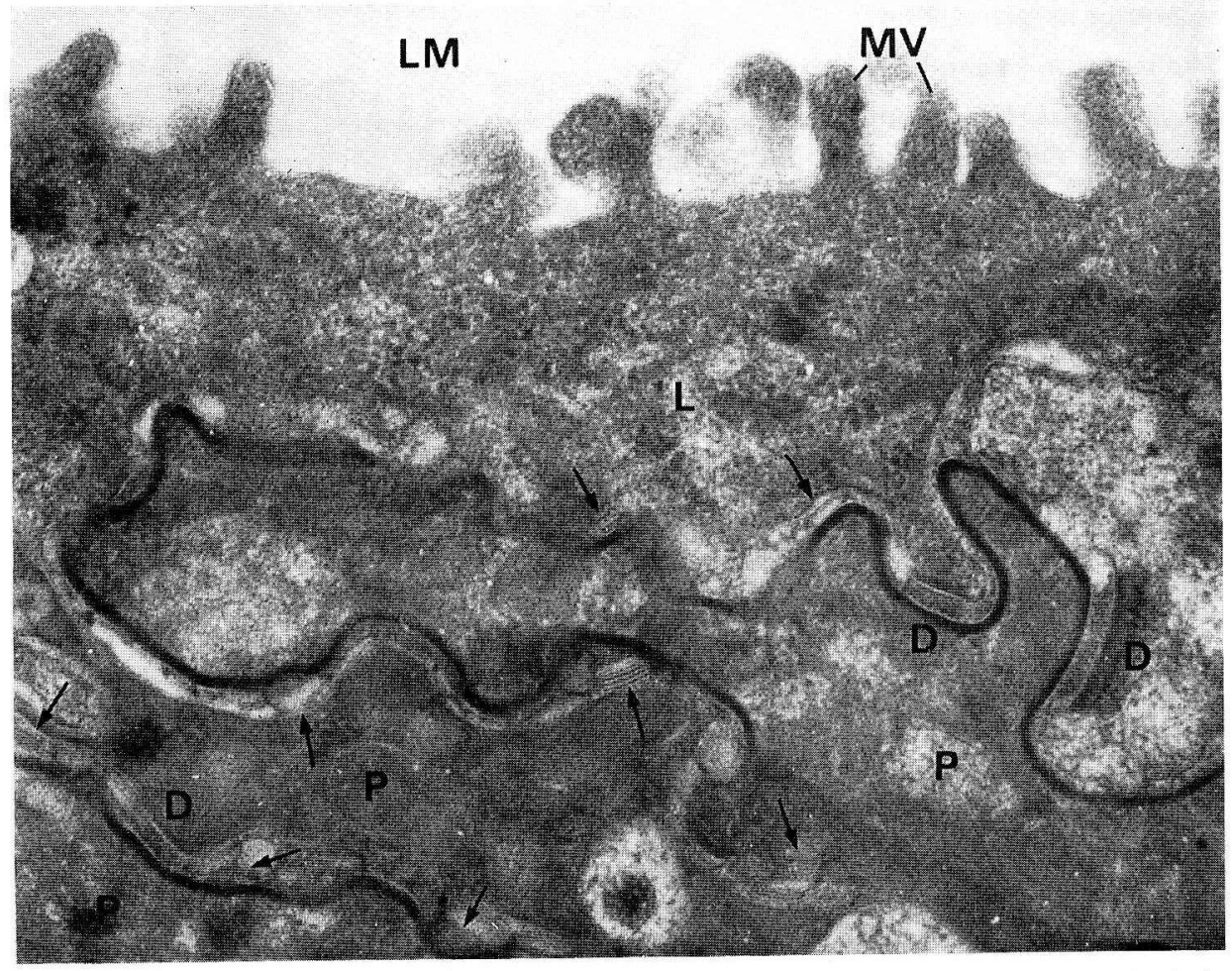

Fig. 7. A part of the intraepidermal sweat duct at the level of the stratum granulosum; both the luminal $(L)$ and peripheral $(P)$ cells become opaque and are filled with dense, amorphous or granular substances. Cell membranes of peripheral cells become thickened. Lamellar structures derived from lamellar granules are observed in the intercellular space (arrows). Desmosomes $(D)$ are seen, but altered in shape. $L M$ ductal lumen, $M V$ microvilli. $\quad \times 62,000$

Peripheral cells. Peripheral cells are arranged in a single layer in the lower part of the stratum granulosum and two to three layers in the upper part of that layer (Fig. 7). They are readily distinguishable from the adjoining keratinocytes, because they become more flattened and straighter than the latter cells and most of their cell membrane become thickened (Fig. 6, 7). The flattened cytoplasm of the 
luminal cells overlaps one another. Most of the nuclei and cell organelles disappear even in the lower part of the stratum granulosum, though spherical or oval keratohyalin granules, tonofibrils and free ribosomes remain in the cytoplasm. In the upper part, nuclei and organelles cannot be seen and the cytoplasm is filled with dense fibrous or amorphous components, although lucent areas are often seen (Fig. 7). Cell membranes become thicker and denser in most peripheral cells in this level. Lamellar structures derived from lamellar granules are seen in the intercellular spaces and are usually situated in parallel with the cell membrane (Fig. 7). In the lower part of the stratum granulosum (Fig. 6), desmosomes remain between the peripheral cells and adjoining keratinocytes. In the upper part (Fig. 7), the definitely dense attachment plaque becomes obscure. Intercellular contact layer is replaced by a single layer of more uniform density.

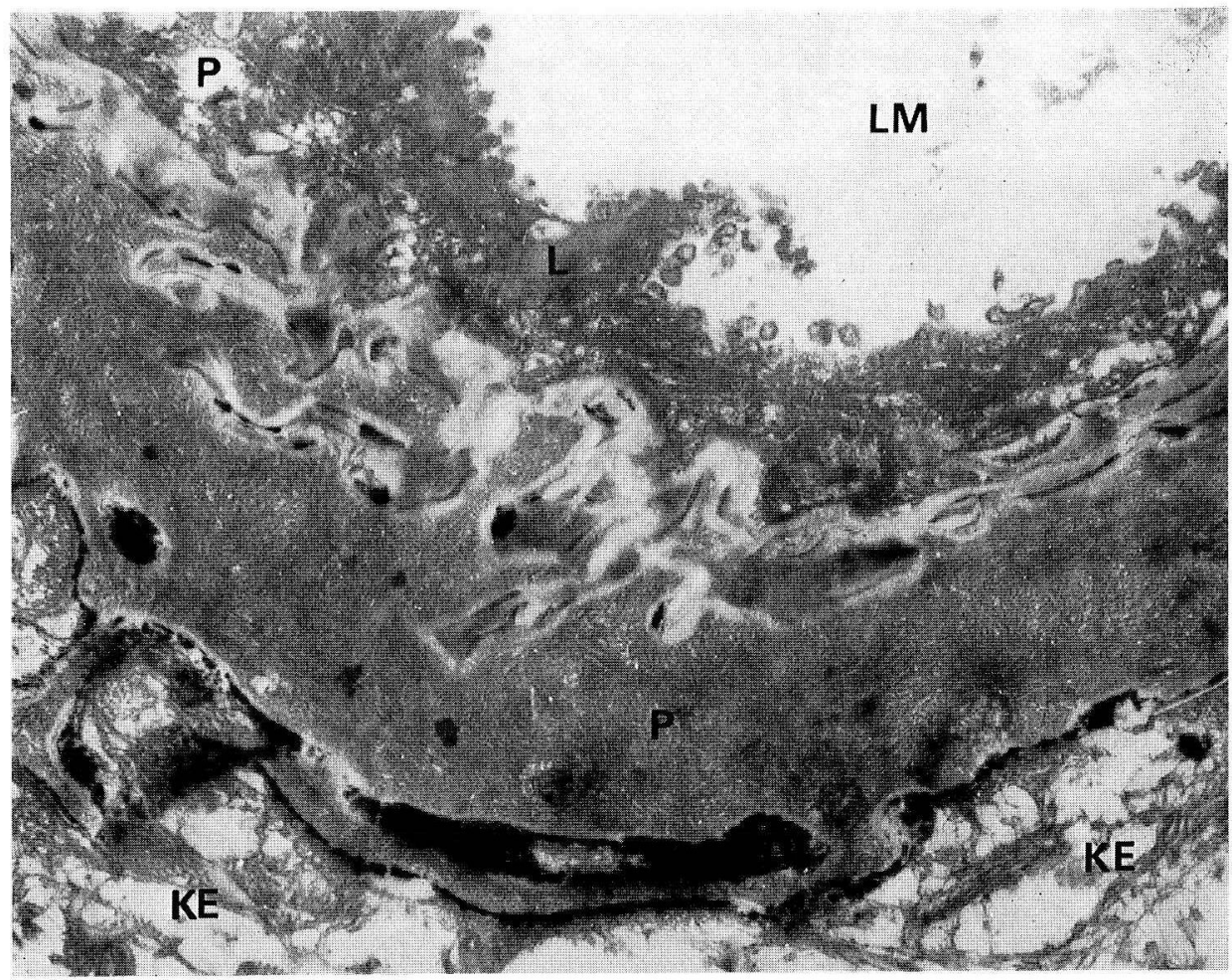

Fig. 8. Acid phosphatase activity of the intraepidermal sweat duct in the stratum granulosum. The reaction products are demonstrated in the intercellular space between the adjoining peripheral cells $(P)$ and between the peripheral cells and the adjacent keratinocytes $(K E)$. L luminal cells, LM ductal lumen. $\times 22,000$

Acid phosphatase activity in this level is prominently demonstrated on the lamellar granules and in the intercellular spaces among the peripheral cells themselves and between the peripheral cells and the adjoining keratinocytes (Fig. 8). At a higher magnification, reaction products are demonstrated on the lamellar structures derived from the lamellar granules in the intercellular space (Fig. 9). 


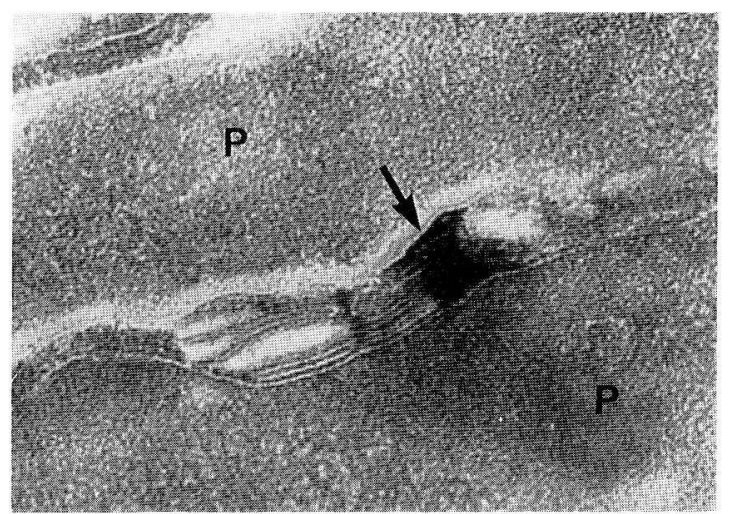

Fig. 9. Acid phosphatase activity is demonstrated on the lamellar structure (arrow) in the intercellular space between the peripheral cells $(P) . \quad \times 88,000$

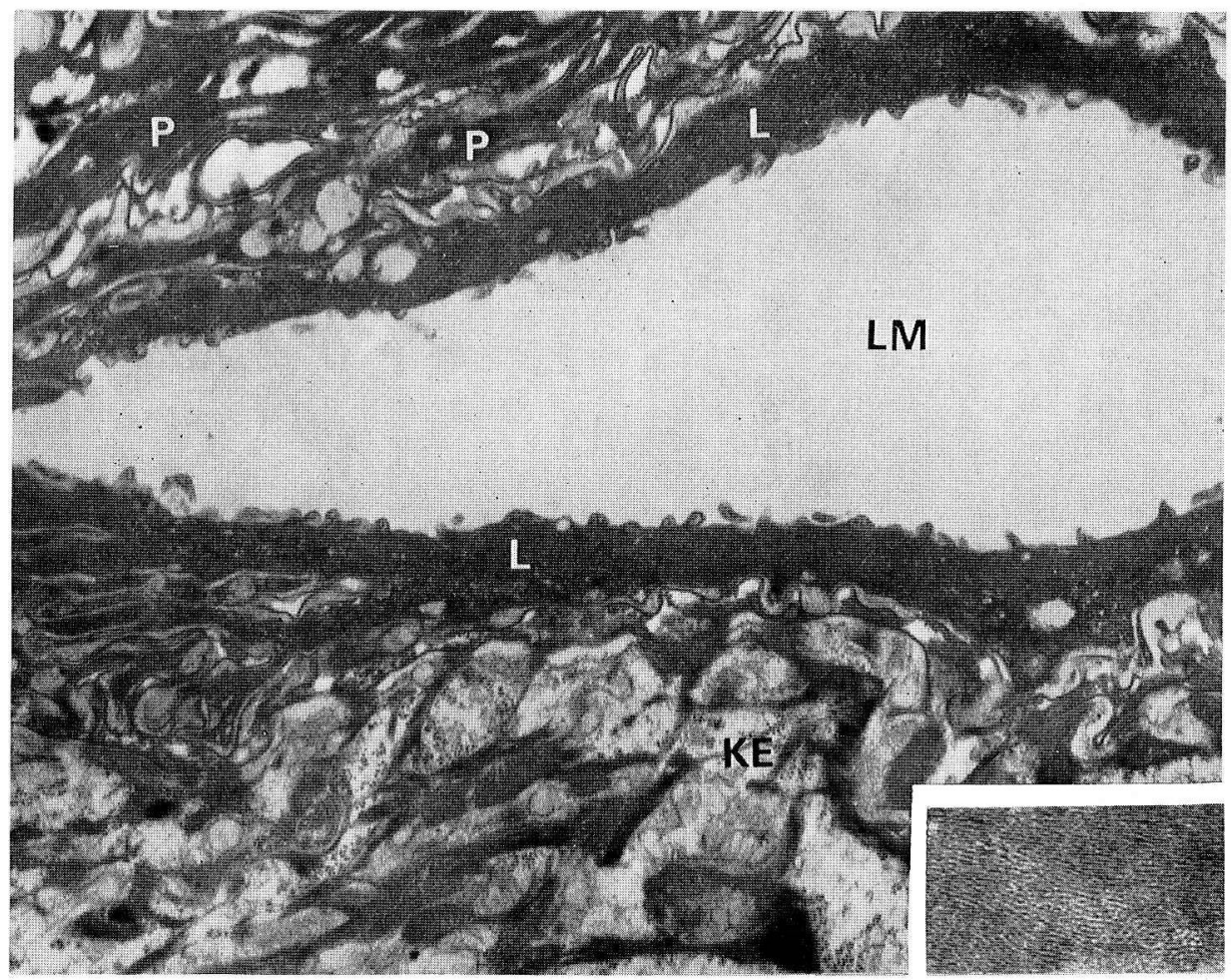

Fig. 10. In the boundary portion between the stratum granulosum and the stratum corneum, both the luminal $(L)$ and peripheral $(P)$ cells become more flattened in thickness and more opaque in density. The peripheral cells interdigitate and the typical keratin pattern is seen in these cells as shown in the inset. Microvilli decrease in number. LM ductal lumen, $K E$ keratinocytes, $\times 11,000$ (inset: $\times 51,000)$ 
Boundary portion between the stratum granulosum and the stratum corneum (Fig. 10).

Luminal cells. The luminal cells at the boundary portion are more flattened and opaque than the stratum granulosum. All the nuclei and cell organelles have disappeared. Along the luminal surface some microvilli are still present and are bent and twisted, though their number is reduced.

Peripheral cells. The peripheral cells arranged in two or three layers are completely flattened, and some lucent areas are left in the cytoplasm. All the nuclei and cell organelles have disappeared. The cytoplasm is often filled with a uniform mass made up of less dense filaments embedded in a dense matrix. This appearance has been called the keratin pattern. A moderately dense substance is seen in the intercellular space.

The stratum corneum (Fig. 11, 12)

Luminal cells. Sometimes, the flattened luminal cells begin to be shed into the ductal lumen in the lower part of the stratum corneum through the loss of their desmosomal attachment to the surrounding peripheral cells (Fig. 11). The luminal cells contain numerous, loosely packed tonofilaments forming a spongy meshwork, though no nuclei and cell organelles can be seen in this level. In the upper part of

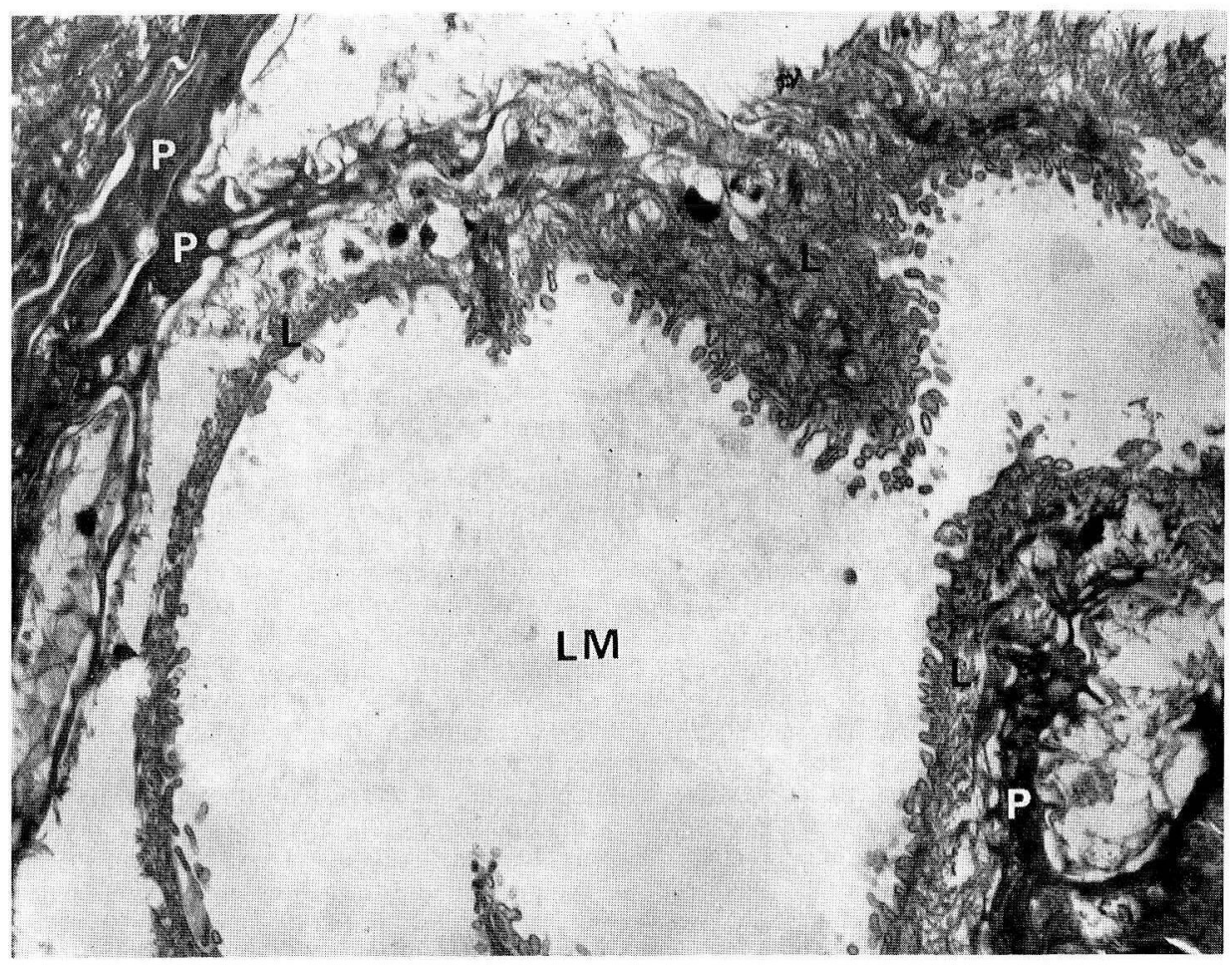

Fig. 11. Cross section of the sweat pore in the lower part of the stratum corneum; luminal cells $(L)$ containing numerous, loosely packed tonofilaments are often shed into the ductal lumen $(L M)$. The cytoplasm of luminal cells is less dense than that of the peripheral cells $(P) . \quad \times 9,500$ 
the stratum corneum, the peripheral cells have been shed into the ductal lumen.

Peripheral cells. The cells become completely flattened and are thinner than

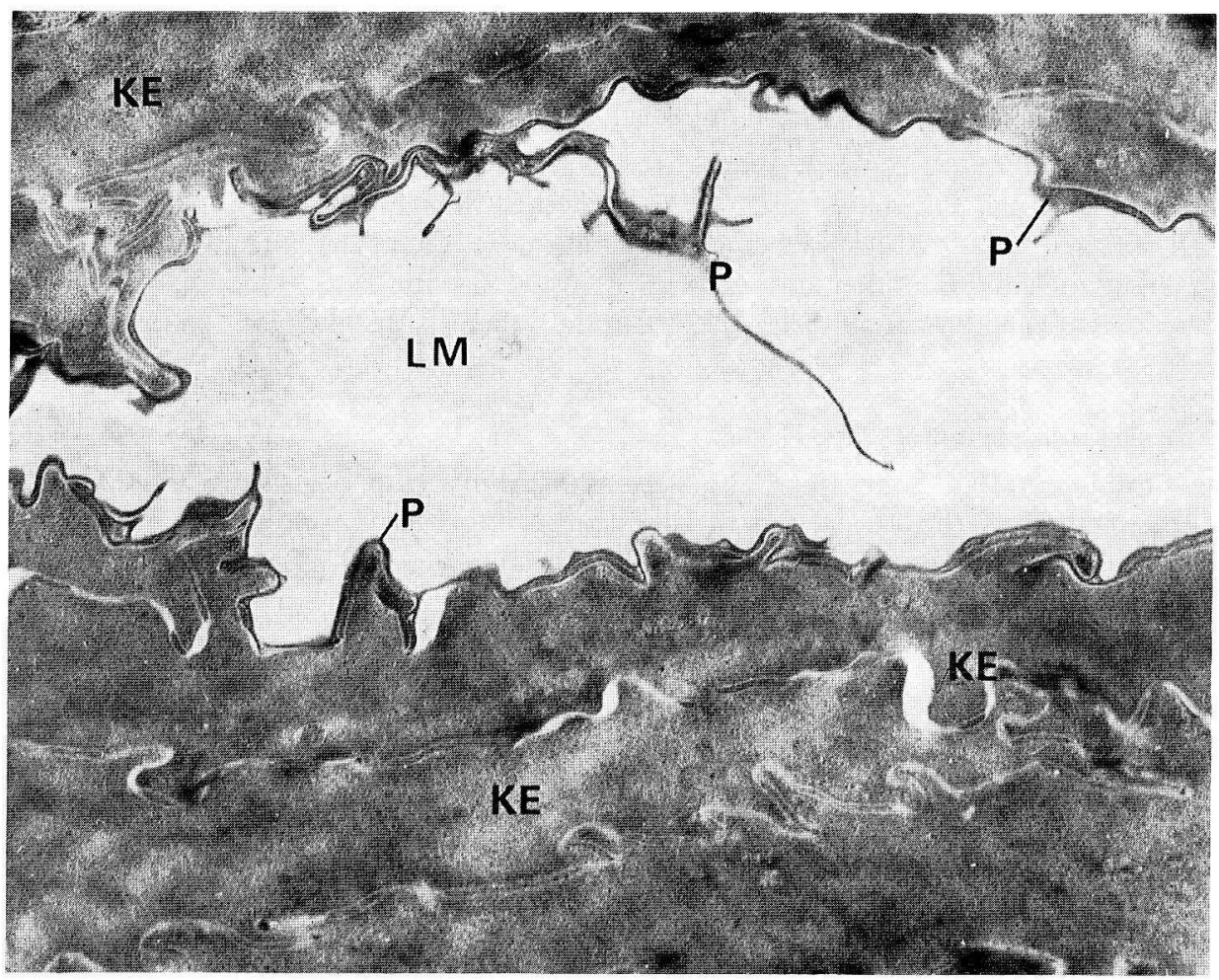

Fig. 12. In the lower part of the stratum corneum, peripheral cells $(P)$ desquamate progressively into the ductal lumen $(L M)$. Typical keratin pattern is seen in the adjoining keratinocytes $(K E)$. The boundary portion between the outermost cells of the intraepidermal sweat duct and the adjoining keratinocytes is indented. $\times 19,000$

Fig. 13. Diagramatic representations summarizing the keratinization of the intraepidermal sweat duct in the mouse foot pad. Schematic diagram by light microscopy is shown in the uppermost left corner. Numbers 1-5 shown in small letters in the intraepidermal sweat duct (ISD) correspond with schematic drawings by electron microscopy $(\mathbf{1}-\mathbf{5})$ at each level of the epidermis. $B L$ basal layer, $S L$ spinous layer, $G L$ granular layer, $H L$ horny layer. In the stratum spinosum $(1,2)$, the intraepidermal sweat duct is composed of a single layer of luminal cells $(L)$ and a single layer of peripheral cells $(P)$. In the lower part of the stratum spinosum (1), numerous, short stumpy microvilli $(M V)$ protrude into the ductal lumen $(L M)$. Keratohyalin granules $(K H)$ and Golgi apparatus $(G)$ are seen in both luminal $(L)$ and peripheral $(P)$ cells. In the upper part of the stratum spinosum (2), spherical keratohyalin granules $(K H)$ increase in number and size. Tonofilaments are bundled into tonofibrils $(T)$ in peripheral cells $(P)$. Lamellar granules $(L G)$ in peripheral cells discharge inner contents into the intercellular space between the luminal and peripheral cells. In the stratum granulosum (3), the intraepidermal sweat duct is composed of a single layer of luminal cells and two to three layers of peripheral cells. In the lower part of the stratum granulosum, peripheral cells become flattened and the cell membrane is thickened. In the upper part of the stratum granulosum (4), both cells become more flattened. Nuclei and most of cell organelles disappear. In the horny layer (5), both cells finally keratinize and begin to be shed into the ductal lumen. $D$ desmosome. 

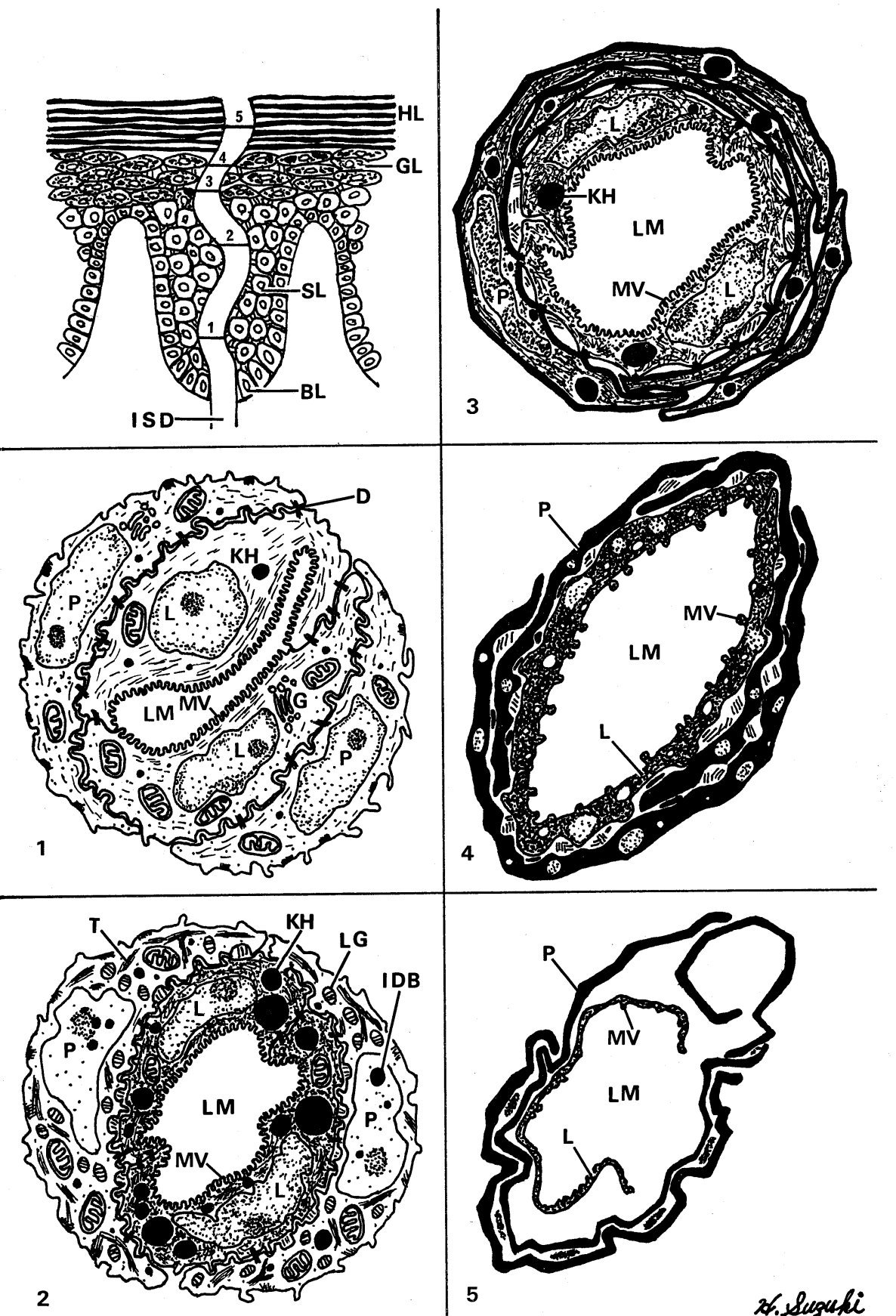

5

26.suguali

Fig. 13. 
the adjoining keratinocytes. They are readily distinguishable from the adjoining keratinocytes due to their thinner cytoplasm (Fig. 12). The nucleus and cell organelles are no longer seen and the electron opaque cytoplasm is filled only with closely packed filaments. As the luminal cells are shed into the ductal lumen, the peripheral cells come to line the ductal wall; then in turn they are shed. In the upper part of the stratum corneum, the duct was lined by one or two layers of completely thin peripheral cells. In the upper layer, the outermost layer of peripheral cells are closely attached to the adjoining keratinocytes (Fig. 12). Desmosomes are much altered, but remnants of intercellular contact layers remain in the intercellular spaces. The surrounding keratinocytes containing the typical keratin pattern in the cytoplasm are larger and thicker than the peripheral cells and closely packed.

\section{Discussion}

By electron microscopy the intraepidermal sweat duct of the mouse foot pad is demonstrated to consist of a single layer of luminal cells and one to three layers of peripheral cells. To the lower part of the stratum granulosum, the peripheral cells are in a single layer, and, from the upper part of the stratum granulosum, they are in two or three layers, though the luminal cells are in a single layer throughout the path of the intraepidermal sweat duct. As the intraepidermal sweat duct ascends through the epidermis, it begins to keratinize progressively much earlier than the surrounding keratinocytes. The luminal cells keratinize incompletely, while the peripheral cells keratinize completely, and then these keratinized cells are shed into the ductal lumen.

In the luminal cells, tonofilaments are abundant in the cytoplasm, especially at the periluminal area and they have little tendency to form tonofibrils. Fine filamentous components are contained in the stumpy microvilli covering the luminal surface. The cuticle observed with the light microscope is attributed to miscellaneous organelles such as stumpy microvilli, intracellular tonofilaments and desmosomes (ZeLICKSON, 1961; Ellis and Montagna, 1961) and the fuzzy coat of the microvilli (Hashimoto et al., 1966). On the other hand, tonofilaments are bundled and form tonofibrils in the peripheral cells as well as in the epidermal keratinocytes.

Keratohyalin granules are first detected in the luminal cells and they appear later in the peripheral cells. They can be seen within an area where free ribosomes aggregate in both cells. Keratohyalin granules observed in cells of the intraepidermal sweat duct are usually spherical or oval in shape and surrounded by numerous ribosomes though they are irregular in shape in the epidermal keratinocytes. These granules are completely independent of fibrilar component and any other organelles. They may exist as droplets in the cytoplasmic matrix as well as lipid droplets (SuzuKI and Kurosumi, 1973; Suzuki et al., 1973). Such spherical keratohyalin granules surrounded by numerous ribosomes have been reported in the keratinizing epithelia of several mammals (Farbman, 1966; Bonneville, 1968; Lavker and Matoltsy, 1970; Jessen, 1970). From the morphological point of view, it is possible that keratohyalin may be produced by free ribosomes and may initially deposit as adroplet independently of any other organelles. The granules may become larger in size and increase in number by their continuous formation, and consequently they may infiltrate into the interfilamentous spaces and embed the tonofilaments (SuzuKi and Kurosumi, 1973; 
SuzuKi et al, 1973).

Sometimes, in the nuclei of the peripheral cells of the upper part of the stratum spinosum, spherical dense granules morphologically identical with intracytoplasmic spherical keratohyalin granules are found. The nuclear dense granules are distributed throughout the karyoplasm, though some of them are occasionally observed around or on the nucleoli. Such nuclear dense granules have been reported in some keratinizing epithelia (Oehmke and Petrey, 1964; Farbman, 1966; Matoltsy and Parakkal, 1967; Jessen, 1970; Raknerud, 1971). Oenmke and Petrey (1964) suggested the possibility that the nuclear dense granules became keratohyalin granules. However, it is impossible at this time to determine whether or not they are realy keratohyalin. From the facts that the nuclear dense granules inconstantly occur in the keratinizing epithelia and are not seen to leave the nucleus, it may be assumed that the nuclear dense granules are not the precursors of the intracytoplasmic keratohyalin granules. The function and origin of the nuclear dense granules remain unknown and further studies are needed.

Lamellar granules of ODLAND (1967) are detected in the cytoplasm of peripheral cells in the lower part of the stratum spinosum, while they are not observed in the luminal cells throughout the path of the intraepidermal sweat duct. They are dispersed through the cytoplasm at this level. In the upper part of the stratum spinosum or in the stratum granulosum, they migrate toward the superficial portion of the cell. Consequently, the internal substance of the granules is discharged into the intercellular space between the luminal and the peripheral cells, as well as that between the peripheral cells and epidermal keratinocytes. WolfF and Holubar (1967) demonstrated acid phosphatase activity on these granules and in the intercellular space in the epidermis of the guinea pig. In the present observation, acid phosphatase activity was demonstrated on the lamellar granules and in the intercellular spaces. At a higher magnification, the activity is often demonstrated on the dense lamellae in the intercelluar space, which may be derived from the lamellar granule. WolfF and Holubar (1967) concluded that the lamellar granules might be special lysosomes and contribute to the desquamation of horny cells, since they contained hydrolytic enzymes represented by acid phosphatase. Recently, НАsнiмото (1971a) stated, however, that the lamellar granules might contain phospholipid, since their lamellar pattern was digested away with phospholipase $\mathrm{C}$ and he concluded that phospholipid might be part of the intercellular cement so he termed the granules cementsomes. On the other hand, Matoltsy and Parakkal (1967) stated that the granule might contribute to the formation of coating and thickening of the cell membrane due to the extrusion of their content into the intercellular space. In our recent study (SuzUKI and Kurosumi, 1973), we proposed two different functions to the lamellar granules because they consist of two different substances, that is, the enzymatic protein and phospholipid arranged in alternating lamellae. The hydrolytic enzymes may possible act for dissolution of the intercellular cement substance resulting in the desquamation of keratinized cells, while the lipid substances may coat the cell surface and protect the cell membrane and protoplasm from digestion by lytic enzymes until their detachment.

At the level of the stratum granulosum, cell membranes of the peripheral cells become thicker with an increased electron density like those of the epidermal 
keratinocytes. On the other hand, throughout the path of the intraepidermal sweat duct, thickening of the cell membrane does not occur in the luminal cells. НАsнiмото et al. (1966) stated that the presence of lamellar granules in the peripheral cells was compatible with the complete keratinization of peripheral cells with thickened cell membranes. However, the thickening process of the cell membrane remains obscure.

In the upper part of the stratum granulosum, both the luminal and peripheral cells finally keratinize. Typical keratin pattern is seen in the peripheral cells, but it is not seen in the luminal cells. It is possible that the keratin pattern may not occur in the luminal cells since the tonofibrils are less developed. In the lower part of the stratum corneum, the keratinized ductal cells begin to desquamate into the lumen. Sometimes, the luminal cells which are falling into the lumen can readily be distinguished from the peripheral cells, because the former appear lighter and contain more numerous bundles of tonofilaments. It seems likely that the luminal cells may desquamate into the lumen without dense condensation of the tonofilaments and formation of keratin pattern. Sometimes, it seems that the luminal cells somewhat swell in this level. Concerning such findings, Zelickson (1961) stated that the luminal cells might be capable of swelling under humid conditions.

Desmosomes observed on the cells of the intraepidermal sweat duct are smaller than those of the epidermal keratinocytes. As the duct ascends through the epidermis, desmosomes alter in shape progressively. In the upper part of the stratum granulosum, the attachment plaque becomes obscure and the intercellular contact layer is replaced by a single layer of more uniform density. In the stratum corneum, only thicker, dense remnants of intercellular contact layers remain in the intercellular space.

From all the findings of the present study, it is concluded that the luminal cells may keratinize incompletely, while the peripheral cells may keratinize completely resembling the epidermal keratinocytes.

A diagrammatic representation on the keratinizing process of the cells in the epidermal sweat duct is shown in Figure 13.

In the human being, it seems to be generally supported that the sweat may be reabsorbed in the eccrine sweat duct, since human sweat is hypotonic with respect to sodium and chloride. Munger and BRusiLow (1961) stated that the (intradermal) eccrine sweat duct in the human was capable of reabsorbing sodium and chloride. SHIBASAKI and Iто (1967) emphasized that the cuboidal cells of the transitional portion in the dermis reabsorb certain constituents of the secretion of sweat gland by means of pinocytotic activity. The transitional portion cannot be observed in the mouse. ZELICKSON (1961) stated that, even in the epidermis, the luminal cells were morphologically comparable to those of the proximal convoluted segment of the renal tubule and that they might play an active part in reabsorbtion of sweat. Recently, HAsHIмото (1971b) indicated that there was no connection between the ductal lumen and the intercellular spaces of the surrounding epidermal cells, since the distal tight junction between the luminal cells prevented the permeation of lanthanum. Even in the mouse it is supposed from the present study that sweat may not be reabsorbed in the keratinizing portion of the intraepidermal sweat duct, because the lumen is surrounded by the strong ductal wall which keratinizes much earlier than the rest of the epidermis. 
Acknowledgement. The author wishes to express his sincere thanks to Prof. K. Kurosumi and the members of the Department of Morphology, Institute of Endocrinology, Gunma University.

\title{
マウスの表皮内汗管の電子顕微鏡的研究
}

\author{
鈴 木 啓 之
}

マウス足底の表皮内汗管を電子顕微鏡で観察した.

表皮内汗管は, 管腔に面した 1 層の管腔細胞とそれをとりまく $1 \sim 3$ 層の外周細胞と からなる．表皮内汗管の細胞は周囲のケラチノサイトよりは早期に角化する.

管腔細胞は不完全に角化する. 多数の張微原線維がみとめられるが，張原線維を形成 する傾向はほとんどない，多数のリボゾームによりとりかこまれた球形のケラトヒアリ ン顆粒がみとめられる。しかし Odlandの層板顆粒はみとめられず，細胞膜肥厚もおこ らない，管腔細胞はケラチン パターンを形成することなく管腔内に㔀脱する.

外周細胞は表皮ケラチノサイトと同様に完全に角化する。張微原線維は豊富であり， それらの多くは張原線維を形成する. 層板顆粒は有棘層深部の高さでみとめられ, 顆粒 内容を相接する外周細胞の細胞間陌ならびに外周細胞と管腔細胞の間の細胞間隙に放出 する。酸性フォスファターゼ活性は, 細胞内の層板顆粒ならびに顆粒に由来する細胞間 隙の層板構造上に検出される. 球形のケラトヒアリン顆粒は外周細胞にもみられる. 時 として 球形のケラトヒアリン顆粒によく似た球形の暗調顆粒が核内に観察される. 顆粒 層の高さで, 外周細胞の細胞膜は肥厚し, 細胞質には定型的ケラチンパターンが観察さ れる，完全に角化した外周細胞は角質層下部で管腔内に剶脱する.

\section{References}

Barka, T. and P. J. Anderson: Phosphatase. In: Histochemistry. Theory, practice and bibliography. New York-Evanston-London, Harper and Row Publishers, 1963. (p. 212-256).

Bonneville, M, A.: Observations on epidermal differentiation in the fetal rat. Amer. J. Anat. 123: 147-163 (1968).

Charles, A.: An electron microscope study of the eccrine sweat gland. J. invest. Dermatol. 34: 81-88 (1960).

Ellis, R. A.: Eccrine, sebaceous and apocrine glands. In: (ed. by) A. S. Zelickson: Ultrastructure of normal and abnormal skin. Philadelphia, Lea and Febiger, 1967. (p. 132-162).

Steigleder: Handbuch der Haut- und Geschlechtskrankheiten, Normale und physiologische Anatomie der Haut. I. Berlin-Heidelberg-New York, Springer-Verlag, 1968, (S. 244-263).

Ellis, R. A. and W. Montagna: Electron microscopy of the duct, and especially the cuticular border of the eccrine glands in Macaca mulatta. J. biophys. biochem. Cytol. 9: 238-242 (1961).

Farbman, A. I.: Morphological variability of keratohyalin. Anat. Res. 154: 275-285 (1966).

Hashimoto, K.: Cementsome, a new interpretation of the membrane-coating granules. Arch. dermatol. Forsch. 240: 349-364 (1971a).

: Demonstration of the intercellular spaces of the human eccrine sweat gland by lanthanum, II. The duct. J. Ultrastr. Res. 37: 504-520 (1971b). 
Hashimoto, K., B. G. Gross and W. F. Lever: Electron microscopic study of the human eccrine gland. J. invest. Dermatol. 46: 172-185 (1966).

Hibbs, R. G.: The fine structure of human eccrine sweat glands. Amer. J. Anat. 103: 201-217 (1958).

Jessen, H.: Two types of keratohyalin granules. J. Ultrastr. Res. 33: 95-115 (1970).

Kurosumi, K.: In: (ed. by) Kanto Branch of Japanese Society of Electron Microscopy: Preparation techniques for electron microscopy (Japanese text). Tokyo, Seibundo-Shinkosha. 1970. (p. 303).

Kurosumi, K. and U. Kurosumi: Electron microscopy of the mouse plantar eccrine sweat glands. Arch. histol. jap. 31: 455-475 (1970).

Lavker, R. M. and A. G. Matoltsy: Formation of horny cells. The fate of cell organelles and differentiation products in ruminal epithelium. J. Cell Biol. 44: 501-512 (1970).

Lobitz, W. C., J. B. Holyoke and W. Montagna: The epidermal eccrine sweat duct unit. A morphologic and biologic entity. J. invest. Dermatol. 22: 157-158 (1954).

Luft, J. H.: Improvements in epoxy resin embedding methods. J. biophys. bifchem. Cytol. 9: 409-414 (1961).

Matoltsy, A. G. and P. F. Parakkal: Keratinization. In: (ed. by) A. S. Zelickson: Ultrastructure of normal and abnormal skin, Philadelphia, Lea and Febiger, 1967. (p. 76-104).

Montagna, W.: The eccrine sweat glands. In: The structure and function of skin. 2nd ed., New York, Academic Press, 1962. (p. 312-367).

Munger, B. L. and S. W. Brusilow: An electron microscopic study of eccrine sweat glands of the cat foot and toe pads. Evidence for ductal reabsorbtion in the human. J. biophys. biochem. Cytol. 11: 403-417 (1961).

Odland, H. J. and T. H. Reed: Epidermis. In: (ed. by) A. S. Zelickson: Ultrastructure of normal and abnormal skin, Philadelphia, Lea and Febiger, 1967. (p. 54-75).

Oehmke, H. J. und G. Petrey: Beobachtungen über das Auftreten von Keratohyalingranula in Zellen. Experientia 20: 422-423 (1964).

Raknerud, N.: Two types of keratohyalin in the epidermis of the mouse. J. Ultrastr. Res. 36: 548-549 (1971).

Shibasaki, S. and T. Ito: Electron microscopic study on the duct of the human eccrine sweat gland with the special remarks on the transitional portion epithelium. Arch. histol. jap. 28: 285-312 (1967).

Suzuki, H. and K. Kurosumi: Lamellar granules and keratohyalin granules in the epidermal keratinocytes, with special reference to their origin, fate and function. J. Electron Microscopy. 21: 285-292 (1973).

Suzuki, H., K. Kurosumi and C. Miyata: Electron microscopy of spherical keratohyalin granules. J. invest. Dermatol. 60: (1973, in press).

Wolff, K. und K. Holubar: Odland Körper (membrane coating granule, Keratinosomen) als epidermal Lysosomen. Ein elektronenmikroskopisch-cytochemischer Beitrag zum Verhornungsprozess der Haut. Arch. exp. Dermatol 231: 1-19 (1967).

Zelickson, A. S.: Electron microscopic study of epidermal sweat duct. Arch. Dermatol. 83: 106-111 (1961).

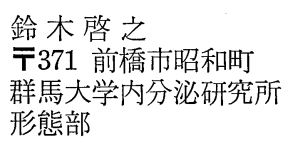

鈴木啓之 群馬大学内分泌研究所 形態部

\author{
Dr. Hiroyuki Suzuki \\ Department of Morphology \\ Institute of Endocrinology \\ Gunma University \\ Maebashi, 371 Japan
}

